\title{
The Role of Strategic Analysis in the Performance of Structural Projects According to KPI Indicators - Field Research in State Company for the Implementation of Transport Projects
}

\author{
Rukaya Abdul Raheem Kareem / Researcher, Ass.Prof. Dr .SanaaAbdul Raheem Saeed/ Supervisor \\ University of Baghdad / college of Administration \&Economics/ Business Management
}

DOI: $10.37648 /$ ijrssh.v10i03.032

Received: $20^{\text {th }}$ June, 2020; Accepted: 21st July, 2020; Published: $18^{\text {th }}$ August,2020

\begin{abstract}
Our research came to clarify the role of strategic analysis of the internal and external environments in the performance of construction projects according to the KPI. Construction projects are just like any business that needs a management approach that enables it to identify the level of performance and whether it is able to accomplish the work required of all according to the schedule Prepared for the completion of these works and in order to identify the level of performance, the system must be available through which performance is measured, and in order to achieve the main purpose of the research, the field research method was used by conducting the initial survey to determine the best indicators to measure the performance of the construction project and then using the questionnaire method as a main tool for data collection The research, as the questionnaire was designed based on a group of sources and literature according to the "five-year Likert scale The statistical analysis was done to prove the research hypotheses through the statistical analysis program spss 22, as a set of conclusions were reached, the most prominent of which was the presence of a strong correlation and influence between the strategic analysis and the performance of the construction project according to the main performance indicators kpi, so the more the organization studies and analyzes its internal and external environment and gets to know More on the opportunities and threats surrounding them and invested their strengths and reduced their weaknesses whenever this helped them in the speed of response to the environmental changes surrounding them in a way that leads to improving the performance of its projects and improving its performance as a whole
\end{abstract}

Keywords: Strategic Analysis ,Structural Project, Key Performance Indicators

\section{RESEARCH METHODOLOGY FIRST TOPIC :}

\section{1-Research Problem}

This research came as an attempt to answer the following questions:
1- What are the best indicators that can be taken as the main indicators through which to measure the performance of the construction projects adopted by the researched company?

2- Does the surveyed company use KPI's in measuring the performance of its construction projects? 
3- What is the role of the strategic analysis of the internal and external environments of the organization in the performance of construction projects according to the "KPI" ?"

\section{2-Research Importance}

The importance of this research is highlighted as it deals with an important part in the performance of construction projects by linking this process with strategic analysis, as the importance of the research stems from the importance of its variables, namely:

1- Attempting to determine the appropriate scale by which to identify the good performance of the construction project in order to improve and develop performance at the level of projects adopted by the researched company and thus improve the overall performance of the organization as a whole.

2- The importance of research also comes from the absence of major indicators to evaluate the performance of the construction project in Iraq.

.3- Research Objectives: The objectives of the research are the following points

1- Demonstrate the depth of public sector companies 'understanding of the importance of strategic analysis and its effective role in improving the performance of their current and future projects.
2- Determine the most important main indicators to measure the performance of construction projects to find the optimal system for measuring performance in the construction project to enable the projects to be successfully managed and to ensure that they achieve the goals

3- Identify the extent of the relevance and impact of the strategic analysis as a major variable in the performance of the construction project as a dependent variable

\section{4- Research Hypothesis}

\section{First: the link hypothesis}

There is a statistically significant significant correlation relationship between the independent variable (strategic analysis) and the dependent variable (construction project performance according to kpi indicators(

\section{Second: the hypothesis of impact}

There is a significant statistically significant impact relationship between the independent variable (strategic analysis) and the dependent variable (construction project performance according to kpi indicator

\section{5- The Hypothesis Figure of Research}




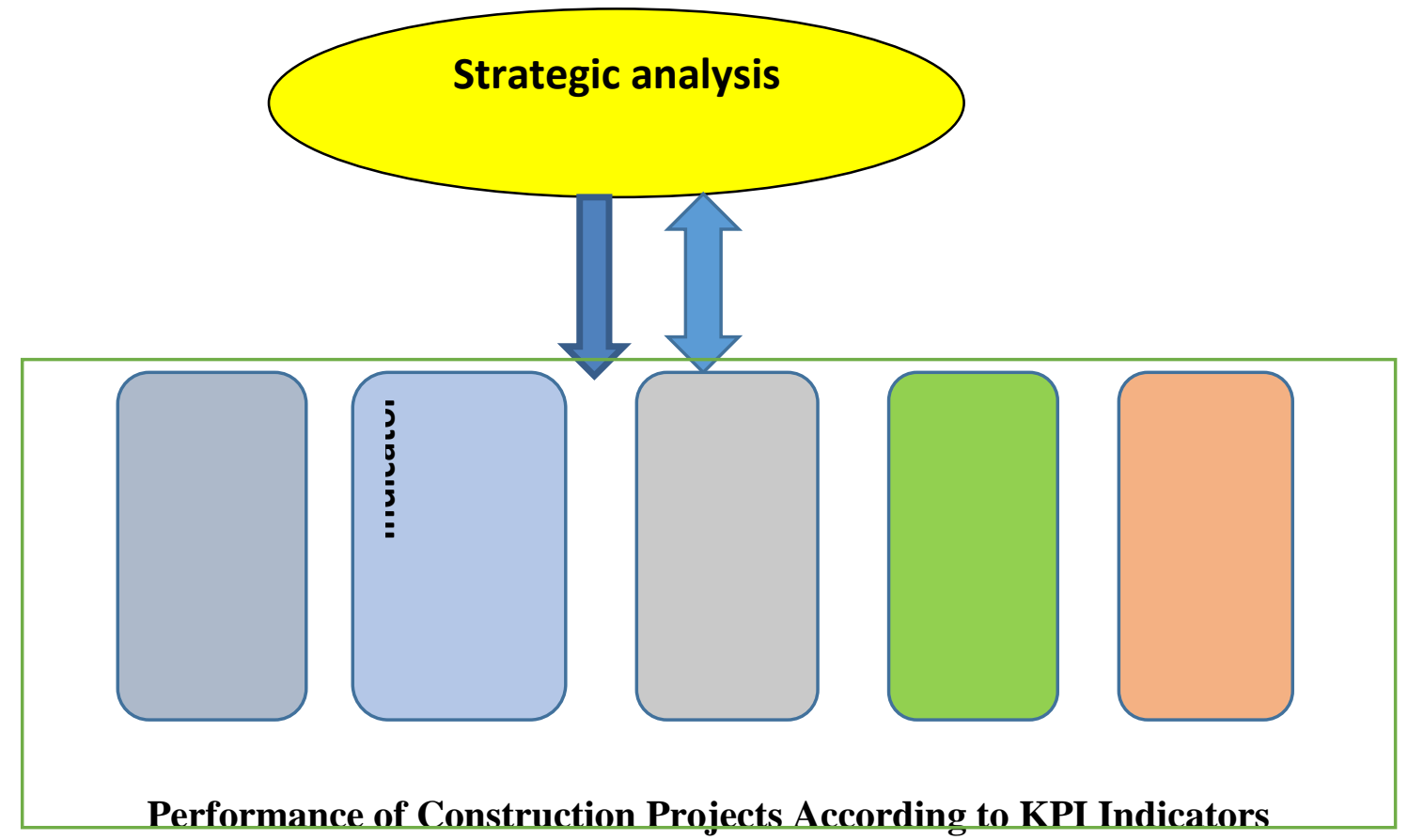

Figure (1 ) The Hypothesis Figure Of Research

\section{6- Research Community \& Sample}

The research community in the transport sector is represented by the State Company for the Implementation of Transport Projects, which is one of the formations of the Ministry of Transport, Regarding the research sample, It was 50 employ from Different Departments of the state .

\section{SECOND TOPIC : THEORETICAL SIDE}

\section{First :Strategic analysis}

1-Concept of Strategic analysis :(Al-Husayni, 2000: 119) states that the best means for responding to environmental changes are those that allow strengthening and enhancing strengths and using them in exploiting available opportunities and avoiding potential threats, as well as means that contribute to eliminating weaknesses or reducing their effects to a minimum, and these means are Through the strategic analysis process

)Johnson and Scholes, 1988) defined strategic analysis as a group of methods used by senior management to determine the extent of change in the external environment and to determine the competitive advantage or distinctive competencies of the organization to enable it to control its internal environment so that this contributes to increasing the ability of the top management to determine Its objectives and strategic position. (Al-Jader, 2007: 15)

\section{2- Dimensions ofOrganizational Environment}

The environment is classified into three Dimensions (Al Douri, 2005: 83)

A- The first: the overall external environment, which falls outside the organization's borders and scope of control. These factors are represented by economic environment factors, social and cultural environment factors, technological environment factors, demographic factors, and political and legal environment factors.

B- The second: the industry environment, and it is sometimes called the task environment or tasks. It is located on the borders of the organization and includes consumers, suppliers, competitors ... etc.

C- The third: It is the set of internal factors that include the philosophy of the organization, the type of senior management, the values, culture and attitudes of individuals and groups in the organization and identifying aspects of the strengths and weaknesses of the organization in order to strengthen the strengths and arrest weaknesses 


\section{3-Analysis of the general external environment:}

(Al-Ghalibi and Idris, 2015: 258-256) states that the general external environment refers to the sum of the economic, social, cultural, political and technological variables or factors within which the organization operates and is affected by it and exchanged influence with it.

4- Analysis of the external environment (industry environment or task environment):

Industry environment means the field of industry or group of companies that produce the same product or provide the same service, as examining the group of shareholders or stakeholders such as suppliers and customers is an important part of the analysis of the industry environment. (Wheelen and Hunger, 2014: 70)

\section{5-Analyzing the internal environment:}

The main purpose of the strategic analysis of the internal environment is to assess and audit the status of the organization to determine its strengths and weaknesses, in order to enable it to identify the areas that are characterized by it and those that involve weaknesses, through the analysis of capabilities, financial, technical, human resources and their skills. Marketing capabilities and others, and thus this analysis provides a list in which the organization lists its strengths and weaknesses to choose the appropriate strategy for the organization's competitive position. (Yassin, 2002: 82)

\section{Second: Performance Of Construction Projects According To KPI Indicators:}

\section{1- Concept of Structural Project Performance: (} Parmenter (2010: 4) indicates that the KPI represents a set of measures that focus on certain aspects of organizational performance that have more impact on achieving the current and future success of the organization. It can also be said that they represent a set of data that are used to reach measuring the performance of project operations and thus it helps the organization in identifying and measuring progress towards achieving its organizational goals through the progress it achieves in its projects. In the pre-1980s, project performance was determined by narrow factors related to determinants of cost, time and specification, but with the development of research and studies between the eighties In the 1990s, a common agreement was reached that the success of the project in its performance has other dimensions, and that measures of success of performance have different methods and times. (Peter \&Zakariya, 2014: 451-452)

\section{3-Diverse frameworks for key performance indicators}

Many Research, studies and reports seeks to define key performance indicators in the building and construction sector have continued in many countries such as the United States of America, Australia, Canada, China, Thailand, Saudi Arabia and others, as the indicators mentioned in these research and reports have been summarized and at the project level. After reviewing ,the most frequent indicators" in the countries of the world were taken into account, which are five indicators:

1- Cost index.

2- Time Indicator.

3- Work Quality Index.

4- Health, safety and environment index.

5- General Satisfaction Index.

\section{THIRD TOPIC: PRACTICAL SIDE}

First: Analyzing the results of the preliminary survey of key performance indicators (KPI) to determine the importance of these indicators and their ability to measure the performance of construction projects

The most important key performance indicators in measuring the performance of construction projects in Iraq were determined by conducting a field survey using a preliminary survey questionnaire that includes the five indicators that were reached through the theoretical side in order to be able to identify indicators of great and little importance and so on by using the five-point Likert scale.And after the questionnaire was distributed to the target sample, they are a group of engineers of the General Company for the implementation of transport projects, which is one of the public sector companies affiliated to the Iraqi Ministry of Transport and specializes in the field of general contracting and engineering worksAs the sample reached (15) engineers who worked in the various departments of the company as well as practiced field work in construction projects and who possess good technical expertise in the field of design, implementation and supervision, and the initial survey form contained two parts, the first of which deals with the personal information of the corresponding person as well as his job title and 
place of work And his years of experience, as for the second section, it included five common indicators to measure the performance of the construction project. In the beginning, the sample individuals who were used by the researcher to conduct the initial survey were described, and then the results of their answers to the initial survey questions of the key performance indicators were analyzed depending on the weighted arithmetic mean and the standard deviation. For each of the five main indicators and their dimensionsAs the results showed that the weighted arithmetic mean of all the indicators included in the questionnaire exceeded the value of the hypothetical mean of 3 according to the five-year Likert scale and as shown in the figure (2), and this shows that the common feature of all individuals of the initial survey sample was their agreement on the importance of all indicators and considered them to be the main indicators. Able to measure the performance of construction projects.

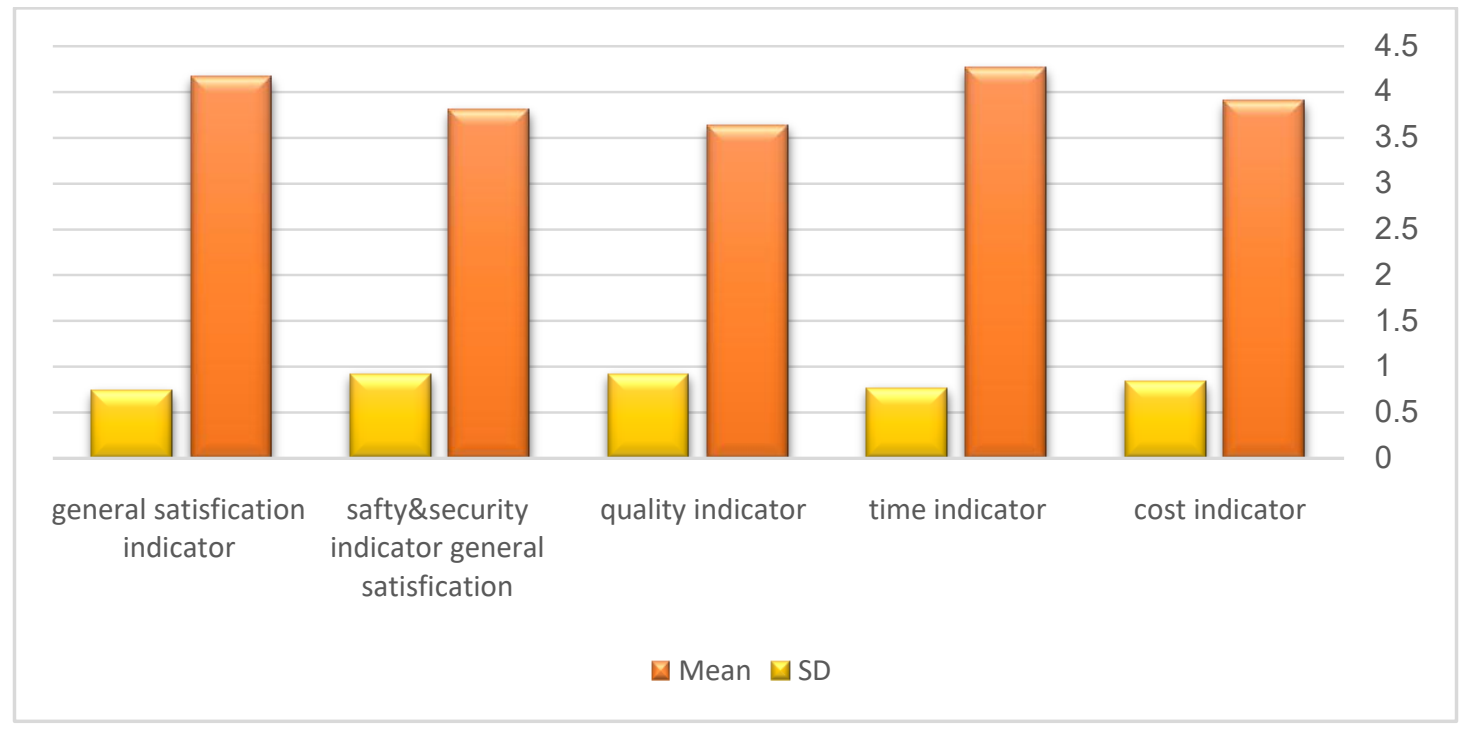

Figure (2) the arithmetic mean and general standard deviations of the initial survey sample answers

Second: Presentation and analysis of the results of the responses of the sample members for the independent and dependent research variables:

Through this axis, the level of the respondents of the sample members to the paragraphs of the questionnaire will be identified for the two variables of the research (strategic analysis and construction project performance according to the KPI), as the weighted arithmetic mean of the items will be compared to ensure the degree of agreement with the paragraphs of the questionnaire, as well as to find the standard deviation for each A paragraph of it to ascertain the extent of consistency in the sample answers regarding the variable, and with regard to the categories that will be adopted for the weighted arithmetic meanings will be as follows:

Largest Value- Smallest Value

$5-1=4$

(category Length)5/4 $=0.8$ 
The categories will be divided as follows:

$$
\begin{array}{ll}
\checkmark & 1.8 \text { I strongly disagree } \\
\checkmark & 1.81-2.60 \text { I don't agree } \\
\checkmark & 2.61-3.40 \text { neutral } \\
\checkmark & 3.41-4.20 \text { agree } \\
\checkmark & 4.21-5.00 \text { Strongly agree }
\end{array}
$$

1 - Results of the sample's degree of agreement on the strategic analysis variable: The value of the general weighted arithmetic mean of the strategic analysis dimension, as shown in Table (), reached (3.7), and it falls under the category (agree), and this indicates that the sample members agree on the scale paragraphs. The low standard deviation of $(0.55)$ and the coefficient of variation 14.86 as another indication of the low dispersion in the sample answers about its weighted arithmetic mean.

Table (2) Analysis of the results of the sample answers to the paragraphs of the strategic analysis

\begin{tabular}{|l|l|l|l|l|}
\hline No. & Question & Mean & C. V. & SD \\
\hline 1 & $\begin{array}{l}\text { The company analyzes the external environment to identify the variables (political, socio- } \\
\text { economic, and cultural) that affect its work in the future. }\end{array}$ & 3.78 & 13.22 & 0.5 \\
\hline 2 & The company identifies opportunities and threats by analyzing the external environment & 3.9 & 10 & 0.39 \\
\hline 3 & $\begin{array}{l}\text { The company analyzes the internal environment to identify the variables (human } \\
\text { resources, financial, administrative) that affect its work in the future. }\end{array}$ & 3.84 & 10.93 & 0.42 \\
\hline 4 & $\begin{array}{l}\text { The company identifies its strengths and weaknesses by conducting an analysis of the } \\
\text { company's internal environment. }\end{array}$ & 4.04 & 14.10 & 0.57 \\
\hline 5 & $\begin{array}{l}\text { Analyzing the external and internal environment helps in developing the company's } \\
\text { vision and mission and determining the required development strategy. }\end{array}$ & 3.78 & 13.22 & 0.50 \\
\hline 6 & $\begin{array}{l}\text { The company works on the participation of various administrative levels in the process of } \\
\text { strategic analysis of the internal and external environment }\end{array}$ & 2.86 & 32.16 & 0.92 \\
\hline & \begin{tabular}{l} 
Total \\
\hline
\end{tabular} & 3.7 & 14.86 & 0.55 \\
\hline
\end{tabular}

2 - Results of the degree of agreement of the sample on the performance of the construction project according to the main performance indicators (KPI): This variable includes five indicators, namely (cost index, time index, quality index, environmental safety and security index, general satisfaction index), as the performance of the construction project was measured according to indicators The main performance in the researched company (the General Company for the implementation of transport projects) is through the paragraphs of the questionnaire, as the sample responses reflected the degree of agreement of the sample members on the paragraphs of the questionnaire assigned to the variable performance of construction projects, as shown in the table (3): 
Table (3) Analysis of the results of the sample answers to the paragraphs of Dimensions of the construction project performance according to the kpi

\begin{tabular}{|l|l|l|l|l|}
\hline No. & $\begin{array}{l}\text { Dimensions of the construction project performance } \\
\text { according to the kpi }\end{array}$ & Mean & $\begin{array}{l}\text { Std. } \\
\text { Deviation }\end{array}$ & C.V.\% \\
\hline 1 & Cost Indicator & 3.72 & 0.66 & 17.74 \\
\hline 2 & Time Indictor & 3.74 & 0.55 & 14.70 \\
\hline 3 & Quality Indicator & 3.40 & 0.87 & 25.58 \\
\hline 4 & Safety \&Security Indicator & 2.94 & 0.84 & 28.57 \\
\hline 5 & General Satisfaction Indicator & 4.04 & 0.47 & 11.63 \\
\hline
\end{tabular}

\section{3 - Testing the hypotheses of correlation:}

The hypothesis of the correlation between the independent variable, which is the strategic analysis variable, and the dependent variable, which is the performance of construction projects according to the key performance indicators (KPI), was tested by finding the correlation coefficient for Spearman, and the results were as follows:

The value of Spearman's correlation coefficient for this hypothesis was $(0.607 * *)$, which indicates the existence of the correlation in a moderate degree and at a level of significance (0.000) which is less than the level of significance $(0.01)$ with the presence of the two signs $(* *)$ which indicates the significance of the correlation between these two variables, Thus accepting this hypothesis which it was stated: There is a significant statistically significant correlation relationship between the independent variable (strategic analysis) and the dependent variable (construction project performance according to kpi indicators), and this confirms that the researched company conducts an analysis of its internal and external environment in order to enable it to identify strengths, weaknesses, opportunities and threats and what it can Of improving the performance of its construction projects.

Table (4) Results of the correlation hypothesis test

\begin{tabular}{|l|l|l|l|l|}
\hline $\begin{array}{l}\text { Independent } \\
\text { variables }\end{array}$ & $\begin{array}{l}\text { Dependent } \\
\text { Variables }\end{array}$ & $\begin{array}{l}\text { The value of } \\
\text { Spearman's coefficient } \\
\text { of correlation }\end{array}$ & Sig. & $\begin{array}{l}\text { The strength of the } \\
\text { correlation relationship }\end{array}$ \\
\hline Strategic analysis & $\begin{array}{l}\text { Performance of } \\
\text { Structural Projects } \\
\text { According to KPI }\end{array}$ & $0.607^{* *}$ & 0.000 & Medium correlation \\
\hline
\end{tabular}

Based on the above, it was reached to accept the hypothesis of correlation between the two variables of the research, which stated: There is a statistically significant moral correlation between the objectives of the company and the performance of the construction project. 


\section{4- Test the effect hypothesis:}

This axis aims to study the effects of the independent variable on the dependent variable, and this is known as the concept of regression, which is intended to predict the degrees of the dependent variable through the degrees of the independent variable, since the regression depends on the correlation, so the regression aims to benefit from the correlation in the prediction ( Ghoneim and Sabri, 2017: 200), and there are many prediction equations, including the simple linear regression equation that we will adopt in our research, which is:

\section{$Y=a+b X$}

\section{... Simple linear regression equation}

$\mathrm{Y}=$ Dependent Variable $\mathrm{a}=$ Constant $\mathrm{x}=$ Independent Variable $\mathrm{b}=$ The value of the marginal slope coefficient, which indicates the percentage change in the value of the adopted variable when there is a change in the value of the independent variable by one unit

As the hypothesis on influence relations states: There is a statistically significant impact significant relationship between the strategic analysis and the performance of the construction project according to the key performance indicators, as the value of the constant a was 41.282, and this means that the value of the dependent variable will not be less than this number even if the value of the independent variable is zero, As for the value of the marginal slope coefficient $b$, it amounted to 1.890 . This indicates that the more the strategic analysis dimension increases by one unit, the performance of construction projects will increase by $18.9 \%$.As for the value of the coefficient of determination R2, it reached 0.338 , which means that the strategic analysis explains what is $33.8 \%$ of the changes that occur in the performance of construction projects. An influence relationship between the strategic analysis and the performance of construction projects KPI, and thus the linear regression equation becomes as follows: $\mathrm{Y}=41.282+1.890 \mathrm{X}$

As Table (5) shows the results of testing the hypothesis of influence between the strategic analysis and the performance of the construction project

Table (5) the results of the impact hypothesis test

\begin{tabular}{|c|c|c|c|c|c|c|c|}
\hline $\begin{array}{l}\text { Dimensions of } \\
\text { Independent } \\
\text { Variable }\end{array}$ & $\begin{array}{l}\text { Dependent } \\
\text { Variable }\end{array}$ & Constant a & $\begin{array}{l}\text { The value of } \\
\text { the marginal } \\
\text { slope } \\
\text { coefficient }\end{array}$ & $\begin{array}{l}\text { The value of the } \\
\text { coefficient of } \\
\text { determination } \\
\text { R2 }\end{array}$ & $\begin{array}{l}\text { The } \\
\text { calculated f } \\
\text { value }\end{array}$ & $\begin{array}{l}\text { The } \\
\text { tabular } \\
\text { f value }\end{array}$ & Notes \\
\hline $\begin{array}{l}\text { Strategic } \\
\text { analysis }\end{array}$ & $\begin{array}{l}\text { Performance } \\
\text { of Structural } \\
\text { projects } \\
\text { According to } \\
\text { kpi }\end{array}$ & 41.282 & 1.890 & 0.338 & 24,561 & 4.04 & $\begin{array}{l}\text { The tabular f } \\
\text { value was } \\
\text { found } \\
\text { according to } \\
\text { "degrees of } \\
\text { freedom } 1,49 \\
\text { and level of } \\
\text { significance } \\
5 \% " \text {. }\end{array}$ \\
\hline
\end{tabular}

And based on the above, it was reached to accept the impact hypothesis, which states: There is a significant statistically significant impact relationship between the strategic analysis and the performance of the construction project. 


\section{FOURTH TOPIC: CONCLUSIONS \& RECOMMENDATIONS}

\section{First : Conclusion}

1- it was concluded that there is a continuous pursuit by companies in their various specializations and businesses.

2- including general contracting companies and engineering works to implement the strategic analysis process, because this concept possesses enabling companies to identify opportunities and threats surrounding them in their external environment in a way that helps them to continue and develop And growth. .

3- it has been achieved that there is a real and effective role for strategic analysis in the performance of construction projects, the more the organization seeks to study and analyze its external and internal environment, the more it can manage and invest its various resources in a manner that will positively affect the performance of its projects and thus its overall performance.

\section{Second : Recommendations}

1- The need for the researched company to adopt modern and contemporary methods in conducting continuous analysis of its external and internal environment in order to be able to identify the external opportunities and threats surrounding it as well as stand on its most important strengths and weaknesses in its internal environment.

2- as we suggest forming a committee concerned with following up the periodic analysis procedure whenever the need arises or the surrounding circumstances change In the company

3- we also found that it is appropriate for the researched company to create a system that enables it to evaluate the performance of its projects before, during and after construction, and that this system is in accordance with the five main performance indicators that were reached through research because of the ability of these indicators to evaluate the performance The construction project is similar to that of the countries of the world that adopt many key performance indicators in measuring and evaluating the performance of their projects.

\section{SOURCES}

1- . Aldoure,ZakariaMutlak,(2003),’Strategic Management:Concepts\&Process\&Cases”,AlyazordiInc.,Amman

2- . Alghalibi,TahirMuhsin\&Waeel,MuhammedSubhi,( 2015),"Strategic Management : An integrated Methodological Perspective",3rd Ed.,WaeelInc.,Amaan

3-Alhussaini,Falah H.,(2000),’Strategic Management: Its Concepts \& processes” ,1st ed., Wael Inc. ,Amman

4- ALJader,Suhair Adel,(2007), "The Relationship Between Strategic Analysis \&alliances Strategy \&Its Impact on Organizational Performance ",A thesis of Phd Degree in Business Administration ,Baghdad University

5- Hanger,G.David\&Wheleen,Thomas 1.,(2014),” Pillars of Strategic Management” ,1st Ed.Alsaghee Inc. Beirut

6 - Parmenter,David , ( 2010),” Key Performance Indicators :Developing ,Implemnting\&Using Winning KPIs” ,2nd Edition ,John Wily \&Sons Inc. , New Jersey

7- Peter,Kurdshi A.\&Zakariya,Baba H.,(2014),’Appraising Effectiveness Of Key Performance Indicators Used by Nigerian Construction Firms", International Journal Of Education And Research,Vol.2 No.12 pp( 460- 541)

8- Yaseen,SaadGhalib,(2007),Strategic Management ,Alyazordi Inc. 